\title{
Explaining Individuals' Behavior towards Their Acquisition of Students' Loan in the US
}

\author{
Asare Eric ${ }^{1}$, Segarra Eduardo ${ }^{2}$ \\ ${ }^{1}$ Texas Tech University, Agricultural Sciences 123, Lubbock, TX, 79409, USA \\ ${ }^{2}$ Texas Tech University, Agricultural Sciences 205-E, Lubbock, TX, 79409, USA \\ Correspondence: Asare Eric, Texas Tech University, Agricultural Sciences 123, Lubbock, TX, 79409, USA.
}

Received: February 16, 2017

Accepted: March 8, $2017 \quad$ Available online: April 5, 2017

doi:10.11114/aef.v4i3.2221

URL: https://doi.org/10.11114/aef.v4i3.2221

\begin{abstract}
This study investigates the behavior of individuals in the US regarding the amount of student loans they might borrow with a two-part model. The model was estimated using the 2013 Survey of Consumer Finance (SCF) data, collected by the Governors of the Federal Reserve System, US, in collaboration with the Statistics and Income Division of the Internal Revenue Service, US. The sampling and imputation errors that are associated with the SCF data were accounted for in the model estimation process to ensure reliable inferences. Old age (41 years and older), previous experience with bankruptcy, attitude towards borrowing to finance education, being Hispanic, employment status, and wage salary were found to be significant variables that can influence the likelihood that a student will borrow a student loan and the amount he/she would borrow. This study also found out that using the SCF data without accounting for the inherent imputation and sampling errors, could lead to biased estimates and incorrect model inferences. The results of this study could help students' loan managers and other relevant stakeholders such as the Federal Government understand the behavior of potential borrowers of student loans to effectively manage the program.
\end{abstract}

Keywords: educational economics, educational finance, state and federal aid, two-part model

JEL Codes: I22, J18, R21, I28, H63, H31

\section{Introduction}

Currently, about forty million people in the US share a total student loan debt of over $\$ 1$ trillion (Federal Student Loan Debt), which is second only to mortgages in the category of households' debt (Dynarski, 2015). This is about 19 percent of the total US national debt of $\$ 19$ trillion. The share of student debt in the national debt would be higher if students' debt to commercial banks and other financial institutions outside the federal government were added to the total Federal Student Loan Debt. The mounting national debt situation in the US, including student loan debt, has caused major concerns to the Federal Government, Policy Think Tanks, and other stakeholders, on how best the Federal Government can sustainably manage the national debt, without significantly affecting the fiscal expenditures of the country and her competitiveness in the world economy (Best and Best, 2014). For instance, the issue of student loan debt and how it could affect the financing of US household's education was a key topic in the recent US political debates.

The student loan debt stock in the US is expected to grow even more. There is evidence that most debtors have been defaulting on their loans, at an increasing rate over the last decade (Lochner and Monge-Naranjo, 2015). Moreover, the demand for student loans has been increasing over the last decade (Lochner and Monge-Naranjo, 2015 and Avery and Turner, 2012). This is not surprising since in-state tuition fees at public four-year colleges and universities have gone up about 54 percent in inflation-adjusted dollars (Li, 2013; Baum and Ma 2002). Further, the financial position of most families in the US has worsened over the years. For example, according to the survey of consumer finances, the real median household income and real median household net worth have fallen by 11 percent and 39 percent, respectively, between 2007 and 2010 (Li, 2013). A possible explanation for the falling median household income and net worth is the declining wages for the average household in recent years (Grafova, 2007). It has also been reported by Lucca et al. (2015) that the tuition costs of institutions in the U.S. are linked to changes in some federal student loan programs. For instance, they observed that tuition rates increased for some institutions exposed to changes in Pell Grant and the unsubsidized federal loan program. Also, Cellini et al. (2014) have observed that, compared to non-Title IV institutions, 
Title IV institutions (institutions that are eligible to participate in the federal student loan program) charge tuition that is about 78 percent higher.

To sustainably manage the student loan debt problem in the US, there is the urgent need to first understand the behavior of students towards student loans. To this end, many studies have contributed to the understanding of students' behavior concerning student loans, in particular, the repayment of student loans and defaults (Lochner and Monge-Naranjo, 2015; Hillman et al. 2014; Li, 2013; Gross et al. 2009; Greiner, 1996; and others). However, there is still very scanty information regarding the factors that influence how much money a student might borrow in the first place. This study will address this issue. Consequently, the objective of this study is to identify the important factors that can influence the amount of student loans that might be borrowed. The results of this study complement the findings of previous studies on student loans (in particular, defaults on student loans) and help provide a better understanding of the behavior of students concerning their interaction with student loans. In particular, it can help student loan managers and policy makers make informed policies to help certain types of students, like minorities and the vulnerable, access student loans.

\subsection{Background Information}

Students' financial aid started in the US prior to the 1800 s, when wealthy families and faith-based institutions provided funds to help students with poor resource backgrounds acquire an education (Fuller, 2014). The essence of the financial aid was to help poor and needy individuals' access education so that they will acquire the essential skills to enable them to obtain good jobs in the economy. This form of students' financial aid transitioned into a students' loan scheme in the early 1800 s, also to help needy students' access to loans at highly subsidized interest rates to finance their education (Fuller, 2014). The first to establish such a student loan was The Harvard University in 1838 (Fuller, 2014). The success of the Harvard student loan program led to similar programs in the other Ivy League and state colleges in the mid- to late-1800s (Cohen \& Kisker, 2009). Currently, student loans are provided mainly by the US federal government through the US Department of Education (Lochner and Monge-Naranjo, 2015). The US Department of Education currently manages about $\$ 713$ billion in Federal Student Aid, which accounts for about 90 percent of the student loan market (Li, 2013). Also, by the National Center for Educational Statistics (2012) estimates, about 55 percent of (11.5 million students) of college and vocational program, students received some form of financial aid from the Federal Government in 2010. This program run by the government is particularly important for sections of the student population who come from poor family backgrounds, and might not be able to access student loans on the commercial market because of bad credit histories. Moreover, by providing this student loan service to help students' access to higher education in the US, the government can improve the quality of the human capital endowment of the country and improve the efficiency of the economy (Avery and Turner, 2012). According to Brown et al. 2015, as of 2012, two-thirds of the total student debt in the U.S is owned by borrowers below the age of 40. The remaining one-third of the total student loan in the U.S is owned by borrowers at or above 40 with the following breakdown: 17 percent, 12 percent, and 5 percent for borrowers between 40-49 years, 50-50 years, and above 60 years, respectively (Brown et al. 2015).

The major Federal student loan schemes in the US are the subsidized Stafford loans, the unsubsidized Stafford loans, the Parent Loans for Undergraduates (PLUS)/GradPlus loan program, and the Perkins Loans (Lochner and Monge-Naranjo, 2015 and Avery and Turner, 2012). The US Federal loan programs are restricted to US citizens, permanent citizens and other eligible residents (like those on asylum and refugee programs) and must have high school degrees or should have passed the General Educational Development Test (GED) (Avery and Turner, 2012).

The Federal Perkins Loan Program was created by the National Defense Education Act of 1958 to give educational loans through collegiate institutions to needy students at a fixed interest rate of 5\% (Lochner and Monge-Naranjo, 2015 and Avery and Turner, 2012). According to Lochner and Monge-Naranjo (2015), this loan scheme is the most preferred students' loan option in the US, because it has the lowest interest rate. However, it is restricted only to students with financial needs, and have some level of funding from the college they attend (Lochner and Monge-Naranjo, 20150). The maximum amount an undergraduate (graduate) student can obtain is $\$ 5500$ (\$8000) for a year (Lochner and Monge-Naranjo, 2015).

Also, the Stafford loan program was created through the Higher Education Act of 1965, to make available student loans to students at subsidized interest rates (Lochner and Monge-Naranjo, 2015, and Avery and Turner, 2012). The interest on the Stafford loan varies from a maximum of $8.25 \%$ (9.5\%) for undergraduates (graduate) students per year (Lochner and Monge-Naranjo, 2015). Again, this loan program is restricted to students who can show they have a financial need, and that they cannot get support from an external source like a parent (Lochner and Monge-Naranjo, 2015). There is also the unsubsidized Stafford loan program, which has comparably higher interest rate than the subsidized Stafford loan program (Avery and Turner, 2012). This loan program was created by congress in 1992, to help fund eligible undergraduate students' education (Lochner and Monge-Naranjo, 2015 and Avery and Turner, 2012). 
Again, the Parent Loans for Undergraduate Students Program (PLUS) created by the Federal Government in 1980 and the GradPlus program allows parents with good credit histories to borrow to fund their dependent child's education (Lochner and Monge-Naranjo, 2015 and Avery and Turner, 2012). The interest on the loan varies up to a maximum of $10.5 \%$, and also charges a fee of $4.3 \%$ of the loan amount (Lochner and Monge-Naranjo, 2015).

\section{Method}

\subsection{Conceptual/Theoretical Model}

Students apply for a student loan to help them finance their education. Essentially, the student undertakes this activity so that he/she can get the essential skills needed to be competitive in the present economy, and the economy of tomorrow. That is, it is a form of an investment. Potentially, students with a college education and beyond are expected to face lower unemployment rates and also earn higher wages and salaries than those with less education (Avery and Turner, 2012; Goldin and Katz, 2008). Other future benefits of higher education are improved health and longer life (Dynarski, 2015). But, it has been observed by Walseman et al. (2015) that student loan debt burden could be associated with poorer psychological functioning. Therefore, in this study the benefit of acquiring student loans is expected to spread across the working life of the student, and beyond. On the other hand, there is a cost associated with acquiring student loans. The main costs are the interest on the loan, the loan principal and other costs (like loan fees). Depending on the loan program, the interest on the loan and the principal are mostly paid in regular installments at least six months after graduation (Avery and Turner, 2012).

Before deciding whether to apply for the loan or not, a rational student will compare the net present value of the stream of benefits associated a student loan to the net present cost of acquiring the loan. The difference between the net present benefit and the net present cost is the utility of acquiring the student loan $\left(\mathrm{U}^{*}\right.$, which is a latent variable). It is assumed that the student is able to estimate a subjective value for $U^{*}$. Given the above information, a student is expected to apply for the loan only when $U^{*}$ is positive.

This decision-making process is assumed to be known only to the decision maker. The mathematical formulation of this latent process is expressed as follows:

$$
\begin{aligned}
& N P B=E\left\{\sum_{t=t g}^{T}\left(A_{t}, S_{t}, O B_{t}, \ldots\right)^{t}\right\}=\varphi\left(A_{t}, S_{t}, O B_{t}, \ldots\right), \quad \operatorname{tg}=0, \ldots, T \\
N P C= & E\left\{\sum_{t=t g}^{T}\left(I_{t}, P_{T}, O C_{t}, \ldots\right)^{t}\right\}=\pi\left(I_{t}, O C_{t}, \ldots\right), t g=0, \ldots, T \\
U^{*}= & \varphi\left(A_{t}, S_{t}, O B_{t}, \ldots\right)-\pi\left(I_{t}, O C_{t}, \ldots\right)>0
\end{aligned}
$$

where: $E$ is an expectation formula; $t g$ is the time after graduation when student starts the loan repayment; $\mathrm{T}$ is the retirement age of the loan student loan beneficiary; NPB is the net present benefit of acquiring higher education: $A_{t}$ is the potential work opportunities available to student after graduation; $S_{t}$ is the potential increased salaries after graduation; $O B_{t}$ is a vector of other benefits that highly educated people might get (such as societal standing and so on); NPC is the net present cost of securing a student loan: $I_{t}$ is the interest payment on the student loan at time $\mathrm{t}$; $P_{t}$ is the principal paid on the loan at time T; $O C_{t}$ is the set of other cost that might be associated with the loan at time t.

Further, this study assumes a two stage decision-making process for a student applying for a student loan. The first stage is whether the student will apply for the loan (when $U^{*}$ is positive or $d=1$ ) or not (when $U^{*}$ is less than or equal to 0 , or $\mathrm{d}=0$ ). This first stage is also called the loan participation equation in this study. Also, given that a student has decided to apply for a student loan $(\mathrm{d}=1)$, he/she then decides on the amount to borrow, also called the intensity stage. This two stage decision-making process of a prospective student loan applicant is expressed in the following mathematical statements:

Loan Participation Stage:

$$
d_{n}=\left\{\begin{array}{c}
1, \quad \text { if } \varphi\left(A_{t}, S_{t}, O B_{t}, \ldots\right)-\pi\left(I_{t}, O C_{t}, \ldots\right)=U^{*}(X \beta)>0 \\
0, \text { otherwise }
\end{array}\right.
$$

\section{Loan Intensity Stage:}

Given that a student applies for a loan, the amount that he/she will burrow is governed by the stochastic process below:

$$
\left.\psi\left(y_{n} \mid d_{n}=1\right), X\right)=\Gamma(X \beta)
$$

where: $\Gamma($.$) is the functional form of the loan intensity equation (assumed to linear in parameters), X$ is a vector of the socioeconomic characteristics of the student; $\beta$ is a vector of parameters that shape the second stage stochastic process.

\subsection{Data and Sampling Procedure}

This study uses the 2013 Survey of Consumer Finances data conducted by the Board of Governors of the Federal Reserve System in cooperation with the Statistics of Income Division of the Internal Revenue Service (Board of Governors of the Federal Reserve System, 2013). The survey uses a dual-frame sample that incorporates an 
area-probability sample and a special list sample developed from a sample of tax records. It contains data on households' assets and liabilities, including student loans. Other information contained in the survey includes pension rights, inheritances, employment information, marital status, information on respondents' loan portfolios (including student loans) and other socioeconomic variables. The survey has five complete data sets on each respondent, each with a sample size of 6,015 . This is because a multiple imputation technique was used to provide values for the missing data contained in the survey.

\subsection{Econometric Model}

Given that the decisions to get a student loan and the amount of money to borrow follow two different stochastic processes, a two-part model is proposed to model the two stage loan application decision levels of the student. This model is chosen over other two-stage decision models, such as the Heckman's two-stage model, because it is flexible and does not make any assumptions regarding the correlation of otherwise of the two decisions (Cameron and Trivedi, 2005). Also, there may be students without student loans. Ignoring such students in the data and using only those with positive student loans to explain the amount of loans they borrow, can potentially produce inconsistent estimates (Cameron and Trivedi, 2005). The two-stage model solves this problem by modeling the extent of loan borrowed given that a student decides to apply for a loan. The set-up of the two-part econometric model is described below:

Following equations (4) and (5), the two-part model density of y for the whole sample is given as:

$$
f(y \mid X)=\left\{\begin{array}{cc}
(1-F(X \alpha)) & \text { if } d=0 \\
F(X \alpha) \Gamma(X \beta) & \text { if } d>0
\end{array}\right.
$$

As already stated the first stage will be modeled using a probit model. The intensity equation will be modeled using ordinary least square (OLS). The likelihood (6) and the log-likelihood (7) associated with equation (8) are given as:

$$
\begin{array}{r}
L L(\alpha, \beta \mid y, X)=\prod_{i=1}^{n}\{1-F(X \alpha)\}^{i(d=0)} *\{F(X \alpha) \Gamma(X \beta)\}^{i(d>0)} ; n=\text { sample size } \\
\log L L(\alpha, \beta \mid y, X)=i(d=0) \ln \{1-F(X \alpha)\}+i(d>0)[\{\ln (F(X \alpha))+\ln (\Gamma(X \beta))\}]
\end{array}
$$

The parameters in the model $(\alpha$ and $\beta$ ) will be estimated by maximizing the log-likelihood associated with equation (8) with respect to the parameters in the model.

\subsection{Model Estimation and Inference}

The two-part model is estimated using the two-part model STATA routine developed by Belotti et al (2015). The same routine will be used to estimate the marginal effects of the regressors in the model. The marginal effects show the combined effects of both first stage and second stage models on the amount of student loan a student would borrow (Belotti et al. 2015). The first part of the model is a probit model, while the second part is a linear OLS model. The data used in the model estimation have very peculiar sampling and econometric characteristics which need to be corrected to ensure consistent estimates, and proper model inferences. First, the missing data in the data were imputed 5 times so that each observation in the SCF survey had 5 separate observations, called implicates (Nielsen and Seay 2015). Also, the unequal probability of selecting households for the survey implies the variance from econometric models estimated from SCF dataset could be biased (Nielsen and Seay, 2015 and Pence, 2000). The two errors are called imputation and sampling errors. The two-part model is estimated using data on each implicate. This means the model was estimated five times using implicates 1 to 5 . To account for the sampling error and get weighted estimates from the two-part model, the model will be estimated by sampling weight (X42001). This will adjust the population weight (X42001) to the US population, and ensure that the sample size of each implicate is consistent with the actual sample size (Shin and Hanna, 2016). Moreover, the standard errors of the estimated models will be derived using the bootstrap method (1000 bootstraps). This can adjust for any heteroscedasticity in the model, and also solve the imputation error (Shin and Hanna, 2016). The coefficients and standard errors for each of the estimated five models will be combined into a one using the repeated imputation inference method (RII) (Pence, 2000 and Montalto and Sung, J. 1996). By this approach, the coefficients of the models will be averaged to obtain one estimate for the combined model. Following Pence (2000), the standard error (SE) for the combined model is calculated as follows:

$$
S E=\sqrt{\left(\frac{N+1}{N}\right) * \text { Imputation Variance }+ \text { Sampling Variance }}
$$

Where:

Imputation Variance $=\sum_{n=1}^{N}\left(b_{n}-b\right)^{2} /(\mathrm{N}-1)$

Sampling Variance $=\sum_{n=1}^{N} V_{n} / N$

$b_{n}$ is the estimate of coefficient (b) from the nth implicate; $V_{n}$ is the variance of $b_{n} ; \mathrm{N}$ is the number of implicates (equals 5 in this study); 


\section{Results and Discussion}

The summary statistics of the variables used in the study are provided in Table 1. It is shown that the average amount of student loan borrowed is $\$ 5031$. Also, about 76 percent and 71 percent of the sample are male and above 41 years old, respectively. Moreover, about 54 percent and 80 percent of the sample are married and feel that it is better to borrow to fund education, respectively. The summary statistics for the rest of the variables are provided in Table 1 .

Table 1. Summary Statistics

\begin{tabular}{lll}
\hline & Mean & Standard Deviation \\
\hline Amount of Student Loan & 5031.05 & 18617.01 \\
Age(above 41) & 0.71 & 0.45 \\
Age (25 to 40) & 0.01 & 0.11 \\
Sex (Male=1, Female=0) & 0.76 & 0.43 \\
Ever Filed Bankruptcy & 0.12 & 0.32 \\
Good to borrow for education expenses & 0.80 & 0.40 \\
Married (Yes=1, No=0) & 0.54 & 0.50 \\
White Race (Yes=1, No=0) & 0.74 & 0.44 \\
Black Race (Yes=1, No=0) & 0.12 & 0.33 \\
Hispanic Race (Yes=1, No=0) & 0.09 & 0.29 \\
Feel Positive about Economy Next 5 Years & 0.47 & 0.50 \\
Feel Negative about Interest Rate Next 5 Years & 0.19 & 0.39 \\
Risk Loving & 0.04 & 0.20 \\
Employed & 0.73 & 0.45 \\
Get Assistant in Financial Emergencies & 0.67 & 0.47 \\
Wage Salary & 120544.70 & 634398.40 \\
\hline
\end{tabular}

The estimated two-part model results show that the coefficients and standard error estimates from each implicate, and the RII method are similar for the first stage probit model. However, the estimates are different for the estimated second stage model. Therefore, it is expected that the imputation and sampling errors associated with the SCF data will not have significant effects on the coefficient estimates and their standard errors in the first stage probit model, but not for the estimated second stage model. Overall, it was found that the estimated models from the five implicates are significant at the 1 percent significant level.

The first stage of the two-part model estimated the probability of a student applying for a student loan using a probit model. The probit model is reported in Table 2. The results show that respondents who have previously filed for a bankruptcy, or feel it is better to borrow for educational expenses, or married, or Black (compared to Asians), or employed, or receive more wage salary are more likely to apply for a student loan at the 1 percent significance level. Also, respondents aged 41 and above are less likely to apply for a student loan at the 1 percent significance level. Moreover, students who are Hispanic (compared to Asians) or male are less likely to apply for a student loan at the 10 percent level.

Table 2. First Stage Probit Model Results

\begin{tabular}{|c|c|c|c|c|c|c|}
\hline & Implicates & & & & & \\
\hline & First & Second & Third & Fourth & Fifth & \\
\hline Probit & & & & & & Technique \\
\hline \multirow[t]{2}{*}{ Age(above 41) } & $-0.81 * * *$ & $-0.81 * * *$ & $-0.81 * * *$ & $-0.80 * * *$ & $-0.81 * * *$ & $-0.81 * * *$ \\
\hline & $(0.05)$ & $(0.05)$ & $(0.05)$ & $(0.05$ & $(0.05)$ & $(0.05)$ \\
\hline \multirow[t]{2}{*}{ Age (25 to 40) } & 0.21 & 0.21 & 0.21 & 0.21 & 0.21 & 0.21 \\
\hline & $(0.17)$ & $(0.17)$ & $(0.17)$ & $(0.17)$ & 0.17 & $(0.17)$ \\
\hline \multirow[t]{2}{*}{ Sex $($ Male $=1$, Female $=0)$} & $-0.14^{*}$ & $-0.15 *$ & $-0.15^{*}$ & $-0.15^{*}$ & $-0.14 *$ & $-0.14 *$ \\
\hline & $(0.06)$ & $(0.06)$ & $(0.06)$ & $(0.06)$ & $(0.06)$ & $(0.06)$ \\
\hline \multirow[t]{2}{*}{ Ever Filed Bankruptcy } & $0.26 * * *$ & $0.27 * * *$ & $0.27 * * *$ & $0.27 * * *$ & $0.27 * * *$ & $0.27 * * *$ \\
\hline & $(0.06)$ & $(0.06)$ & $(0.06)$ & $(0.06)$ & $(0.06)$ & $(0.64)$ \\
\hline \multirow[t]{2}{*}{ Good to borrow for education expenses } & $0.63 * * *$ & $0.63 * * *$ & $0.63^{* * *}$ & $0.63 * * *$ & $0.62 * * *$ & $0.63 * * *$ \\
\hline & $(0.07)$ & $(0.07)$ & $(0.07)$ & $(0.07)$ & $(0.07)$ & $(0.07)$ \\
\hline \multirow[t]{2}{*}{ Married $($ Yes $=1$, No=0 $)$} & $0.18 * * *$ & $0.18 * * *$ & $0.18 * * *$ & $0.17 * * *$ & $0.17 * * *$ & $0.18 * * *$ \\
\hline & $(0.05)$ & $(0.05)$ & $(0.05)$ & $(0.05)$ & $(0.05)$ & $(0.05)$ \\
\hline \multirow[t]{2}{*}{ White Race $($ Yes=1, No=0) } & 0.09 & 0.09 & 0.09 & 0.09 & 0.11 & 0.09 \\
\hline & $(0.10)$ & $(0.10)$ & $(0.10)$ & $(0.10)$ & $(0.10)$ & $(0.10)$ \\
\hline \multirow[t]{2}{*}{ Black Race $\left(\right.$ Yes $\left.=1, N_{0}=0\right)$} & $0.51 * * *$ & $0.51 * * *$ & $0.50 * * *$ & $0.51 * * *$ & $0.52 * * *$ & $0.51 * * *$ \\
\hline & $(0.11)$ & $(0.11)$ & $(0.11)$ & $(0.11)$ & $(0.11)$ & $(0.11)$ \\
\hline
\end{tabular}


Table 2. Continued

\begin{tabular}{|c|c|c|c|c|c|c|}
\hline Hispanic Race $($ Yes $=1$, No=0 $)$ & $-0.24 *$ & $-0.24 *$ & $-0.24 *$ & $-0.24 *$ & $-0.22 *$ & $-0.24 *$ \\
\hline & $(0.12)$ & $(0.12)$ & $(0.12)$ & $(0.12)$ & $(0.12)$ & $(0.12)$ \\
\hline \multirow[t]{2}{*}{ Feel Positive about Economy Next 5 Years } & 0.00 & -0.01 & 0.00 & 0.00 & 0.00 & 0.00 \\
\hline & $(0.05)$ & $(0.05)$ & $(0.05)$ & $(0.05)$ & $(0.05)$ & $(0.05)$ \\
\hline \multirow[t]{2}{*}{ Feel Negative about Interest Rate Next 5 Years } & -0.03 & -0.03 & -0.03 & -0.02 & -0.03 & -0.03 \\
\hline & $(0.06)$ & $(0.06)$ & $(0.06)$ & $(0.06)$ & $(0.06)$ & $(0.06)$ \\
\hline \multirow[t]{2}{*}{ Risk Loving } & -0.20 & -0.20 & -0.20 & -0.20 & -0.20 & -0.20 \\
\hline & $(0.11)$ & $(0.11)$ & $(0.11)$ & $(0.11)$ & $(0.11)$ & $(0.11)$ \\
\hline \multirow[t]{2}{*}{ Employed } & $0.63 * * *$ & $0.62 * * *$ & $0.63 * * *$ & $0.63 * * *$ & $0.62 * * *$ & $0.63 * * *$ \\
\hline & $(0.06)$ & $(0.06)$ & $(0.06)$ & $(0.06)$ & $(0.06)$ & $(0.06)$ \\
\hline \multirow[t]{2}{*}{ Get Assistant in Financial Emergencies } & -0.03 & -0.03 & -0.02 & -0.03 & -0.03 & -0.03 \\
\hline & $(0.05)$ & $(0.05)$ & $(0.05)$ & $(0.05)$ & $(0.05)$ & $(0.05)$ \\
\hline \multirow[t]{2}{*}{ Wage Salary } & $0.00 * * *$ & $0.00 * * *$ & $0.00 * * *$ & $0.00 * * *$ & $0.00 * * *$ & $0.00 * * *$ \\
\hline & $(0.00)$ & $(0.00)$ & $(0.00)$ & $(0.00)$ & $(0.00)$ & $(0.00)$ \\
\hline \multirow[t]{2}{*}{ Constant } & $-1.50 * * *$ & $-1.49 * * *$ & $-1.50 * * *$ & $-1.50 * * *$ & $-1.51 * * *$ & $-1.50 * * *$ \\
\hline & $(0.14)$ & $(0.15)$ & $(0.15)$ & $(0.14)$ & $(0.14)$ & $(0.14)$ \\
\hline
\end{tabular}

The second stage of the two-part model, explains the amount of loan a student will apply given that he/she decides to apply for a loan. Conditional on the student deciding to apply for a loan, the results (Table 3) show that age (above 41 years), Hispanic and sex have negative impacts on the amount of loan a student would borrow, at the 1, 10 and 10 percent significant levels, respectively. Also, an individual who has previously filed for bankruptcy, good feeling towards borrowing to finance education, marriage status, black race, employment status, and wage salary have positive impacts on the amount of loan a student would borrow, all at the 1 percent significance level.

In terms of the marginal effects (Table 4), which show the combined effects of the variables in both parts of the two-part model, this study shows that a unit increase in age above 41 years will cause about $\$ 5589$ reduction in the amount of student loan borrowed at the 1 percent significance level. The study believes that, compared to individuals below 41 years, older people are more likely to have significant savings (through the longer working horizon) and financial security to reduce the need to borrow to finance their education. Compared to an individual who has never filed for bankruptcy, an individual who has previously performed such as exercise will increase the amount of student loan they borrow by about $\$ 2160$, at the 1 percent significance level. An individual who has previously filed for bankruptcy might borrow more to finance their education. This observation is not surprising because such individuals are likely to have bad credit records, and as such reduced potential to obtain credit in the commercial market. Therefore, such individuals might increase the amount they borrow from the Federal Government to make up for possible shortfalls of funds from the commercial market. Also, individuals who feel it is better to borrow for educational expenses, compared to those who do not hold such a position, will increase the amount of student loans they borrow by $\$ 4314$, at the 1 percent significance level. This is not surprising because such individuals might place more value on education and increase their access to it through whatever means available, including student loans. Compared to Asians, an individual who is Hispanic is expected to decrease the amount of student loan they borrow by $\$ 4466$, at the 1 percent significance level. Again, an individual who is employed or receives a higher wage salary is expected to increase the amount of loan they borrow by $\$ 3933$, at the 1 percent significance level. This is contrary to the expectations of this study because it was expected that individuals with such attributes would have more savings and financial security to reduce the need to borrow to finance their education. But, it is possible that the reduced interest of associated with federal student loans might make it attractive for such people to access it to finance their education.

Table 3. Second Stage Regression Results

\begin{tabular}{lllllll}
\hline & Implicates & & & & \\
\hline & First & Second & Third & Fourth & Fifth & RII \\
Regress & & & & & -2666.19 & -3094.26 \\
Age(above 41) & -3420.57 & -2965.34 & -3096.45 & -3322.75 & -26 \\
& $(2424.67)$ & $(2444.19)$ & $(2454.06)$ & $(2444.53)$ & $(2471.080$ & $(2475.07)$ \\
Age (25 to 40) & -4673.25 & -4946.73 & -4430.52 & -5236.59 & -5095.21 & -4876.46 \\
& $(5382.27)$ & $(5500.91)$ & $(5441.56)$ & $(5339.93)$ & $(5306.79)$ & $(5409.41)$ \\
Sex (Male=1, Female=0) & 4795.87 & 4614.83 & 4779.60 & 5032.15 & 4787.02 & 4801.89 \\
& $(2707.51)$ & $(2719.73)$ & $(2724.11)$ & $(2719.12)$ & $(2714.42)$ & $(2723.10)$ \\
Ever Filed Bankruptcy & 2809.66 & 3056.71 & 2587.04 & 2723.86 & 2637.82 & 2763.02 \\
& $2837.61)$ & $(2869.40)$ & $(2844.97)$ & $(2835.93)$ & $(2819.12)$ & $(2850.45)$ \\
Good to borrow for education expenses & 2340.36 & 2118.10 & 2378.05 & 1900.84 & 2219.67 & 2191.40 \\
& $(3802.85)$ & $(3831.64)$ & $(3819.97)$ & $(3805.71)$ & $(3779.02)$ & $(3815.14)$ \\
Married (Yes=1, No=0) & -3085.96 & -3096.69 & -2808.26 & -3355.28 & -2994.07 & -3068.05 \\
& $(3346.63)$ & $(3332.88)$ & $(3354.08)$ & $(3319.43)$ & $(3335.32)$ & $(3346.47)$ \\
White Race (Yes=1, No=0) & -7742.62 & -10500.00 & -8798.12 & -8703.06 & -9918.70 & -9132.50 \\
Black Race (Yes=1, No=0) & $(6678.36)$ & $(6912.61)$ & $(6751.21)$ & $(6722.80)$ & $(6875.18)$ & $(6917.66)$ \\
& -13100.00 & $-17000.00 *$ & $-14600.00 *$ & $-15400.00 *$ & $-16100.00^{*}$ & $-15240.00 *$ \\
& $(6696.85)$ & $(6862.79)$ & $(6752.43)$ & $(6673.01)$ & $(6849.58)$ & $(7008.34)$ \\
\hline
\end{tabular}


Table 3. Continued

\begin{tabular}{|c|c|c|c|c|c|c|}
\hline Hispanic Race (Yes=1, No=0) & $-15100.00 *$ & $-18300.00 * *$ & $-16600.00 *$ & $-16800.00 *$ & $-17500.00 *$ & $-16860.00 *$ \\
\hline & $(6751.65)$ & $(6951.88)$ & $(6821.69)$ & $(6783.73)$ & $(6944.16)$ & $(7004.09)$ \\
\hline \multirow[t]{2}{*}{ Feel Positive about Economy Next 5 Years } & 2033.64 & 2371.16 & 2531.60 & 2715.29 & 2575.37 & 2445.41 \\
\hline & $(2555.58)$ & $(2552.96)$ & $(2530.52)$ & $(2550.31)$ & $(2527.07)$ & $(2563.31)$ \\
\hline \multirow[t]{2}{*}{ Feel Negative about Interest Rate Next 5 Years } & -3001.29 & -3055.10 & -1545.34 & -2079.08 & -1755.69 & -2287.30 \\
\hline & $(2607.35)$ & $(2624.93)$ & $(2737.02)$ & $(2697.75)$ & $(2702.67)$ & $(2809.51)$ \\
\hline \multirow[t]{2}{*}{ Risk Loving } & -1750.83 & -1454.82 & -1644.99 & -1457.08 & -1435.04 & -1548.55 \\
\hline & $(3910.14)$ & $(3943.38)$ & $(4016.24)$ & $(4034.43)$ & $(4020.93)$ & $(3989.10)$ \\
\hline \multirow[t]{2}{*}{ Employed } & -578.64 & 724.77 & 137.18 & -210.65 & 331.99 & 80.93 \\
\hline & $(2916.66)$ & $(2903.74)$ & $(2983.30)$ & $(2892.33)$ & $(2927.02)$ & $(2988.25)$ \\
\hline \multirow[t]{2}{*}{ Get Assistant in Financial Emergencies } & 2389.81 & 2201.08 & 2639.11 & 2420.68 & 2825.12 & 2495.16 \\
\hline & $(2159.35)$ & $(2169.12)$ & $(2139.42)$ & $(2116.97)$ & $(2131.32)$ & $(2163.58)$ \\
\hline \multirow[t]{2}{*}{ Wage Salary } & $0.13 * * *$ & $0.12 * * *$ & $0.11 * * *$ & $0.12 * * *$ & $0.11 * * *$ & $0.12 * * *$ \\
\hline & $(0.04)$ & $(0.04)$ & $(0.04)$ & $(0.03)$ & $(0.04)$ & $(0.04)$ \\
\hline \multirow[t]{2}{*}{ Constant } & $25117.85 * *$ & $27858.85 * * *$ & $25625.34 * * *$ & $26570.48 * * *$ & $26568.50 * * *$ & $26348.20 * * *$ \\
\hline & (7946.95) & $(8047.65)$ & $(7995.13)$ & $(8001.67)$ & $(8077.75)$ & $(8116.62)$ \\
\hline Number of Observations & 6015.00 & 6015.00 & 6015.00 & 6015.00 & 6015.00 & 6015.00 \\
\hline Model Chi-Square & $827.89 * * *$ & $825.37 * * *$ & $828.07 * * *$ & $835.78 * * *$ & $827.05 * * *$ & $828.83 * * *$ \\
\hline
\end{tabular}

Table 4. Marginal Effects Table (Delta Method)

\begin{tabular}{|c|c|c|c|c|c|c|}
\hline & Implicates & & & & & \\
\hline \multirow[b]{2}{*}{ Age(above 41) } & First & Second & Third & Fourth & Fifth & RII \\
\hline & $\begin{array}{l}-5622.752 \\
(521.2781)\end{array}$ & $\begin{array}{l}-5574.236 \\
(516.2589)\end{array}$ & $\begin{array}{l}-5582.664 \\
(519.741)\end{array}$ & $\begin{array}{l}-5642.89 \\
(518.9816)\end{array}$ & $\begin{array}{l}-5523.419 \\
(522.6874)\end{array}$ & $\begin{array}{l}-5589.1922 * * * \\
(522.27)\end{array}$ \\
\hline \multirow[t]{2}{*}{ Age (25 to 40) } & 451.3535 & 437.709 & 524.6637 & 364.6759 & 386.983 & 433.07702 \\
\hline & $(1417.963)$ & $(1435.002)$ & $(1424.1)$ & $(1419.861)$ & $(1411.579)$ & $(1423.36)$ \\
\hline Sex $($ Male $=1$, Female $=0)$ & $\begin{array}{l}-42.22271 \\
(606.5413)\end{array}$ & $\begin{array}{l}-98.96983 \\
(610.8156)\end{array}$ & $\begin{array}{l}-72.83205 \\
(609.3401)\end{array}$ & $\begin{array}{l}-28.2745 \\
(611.123)\end{array}$ & $\begin{array}{l}-35.96117 \\
(608.9868)\end{array}$ & $\begin{array}{l}-55.652046 \\
(610)\end{array}$ \\
\hline Ever Filed Bankruptcy & $\begin{array}{l}2140.986 \\
(635.8124)\end{array}$ & $\begin{array}{l}2217.363 \\
(639.9197)\end{array}$ & $\begin{array}{l}2137.546 \\
(636.6876)\end{array}$ & $\begin{array}{l}2156.454 \\
(637.1605)\end{array}$ & $\begin{array}{l}2145.683 \\
(631.7407)\end{array}$ & $\begin{array}{l}2159.6064 * * * \\
(637)\end{array}$ \\
\hline Good to borrow for education expenses & $\begin{array}{l}4314.098 \\
(821.7122)\end{array}$ & $\begin{array}{l}4309.545 \\
(826.9498)\end{array}$ & $\begin{array}{l}4357.764 \\
(826.1518)\end{array}$ & $\begin{array}{l}4312.331 \\
(827.3589)\end{array}$ & $\begin{array}{l}4276.212 \\
(819.3023)\end{array}$ & $\begin{array}{l}4313.99 * * * \\
(825)\end{array}$ \\
\hline Married $($ Yes=1, No=0) & $\begin{array}{l}559.1486 \\
(681.7879)\end{array}$ & $\begin{array}{l}566.6773 \\
(678.528)\end{array}$ & $\begin{array}{l}618.3804 \\
(679.9041)\end{array}$ & $\begin{array}{l}502.6055 \\
(679.1339)\end{array}$ & $\begin{array}{l}546.0463 \\
(678.9739)\end{array}$ & $\begin{array}{l}558.57162 \\
(681)\end{array}$ \\
\hline White Race $($ Yes=1, No=0) & $\begin{array}{l}-807.4635 \\
(1341.996)\end{array}$ & $\begin{array}{l}-1330.686 \\
(1377.988)\end{array}$ & $\begin{array}{l}-1016.846 \\
(1351.625)\end{array}$ & $\begin{array}{l}-968.66 \\
(1351.791)\end{array}$ & $\begin{array}{l}-1081.479 \\
(1370.59)\end{array}$ & $\begin{array}{l}-1041.02688 \\
(1375)\end{array}$ \\
\hline Black Race $($ Yes=1, No=0) & $\begin{array}{l}868.7082 \\
(1368.739)\end{array}$ & $\begin{array}{l}161.0892 \\
(1395.105)\end{array}$ & $\begin{array}{l}575.959 \\
(1373.946) \\
\end{array}$ & $\begin{array}{l}483.7768 \\
(1368.414) \\
\end{array}$ & $\begin{array}{l}399.5803 \\
(1386.991) \\
\end{array}$ & $\begin{array}{l}497.8227 \\
(1407)\end{array}$ \\
\hline \multicolumn{7}{|l|}{ Table 4. Continued } \\
\hline \multirow[t]{2}{*}{ Hispanic Race (Yes=1, No=0) } & -4156.233 & -4764.062 & -4440.213 & -4478.55 & -4493.567 & $-4466.5246 * * *$ \\
\hline & $(1433.2)$ & $(1470.607)$ & $(1443.175)$ & $(1442.3)$ & $(1461.552)$ & $(1469)$ \\
\hline Feel Positive about Economy Next 5 Years & $\begin{array}{l}341.3015 \\
(548.3761)\end{array}$ & $\begin{array}{l}388.0036 \\
(547.4634)\end{array}$ & $\begin{array}{l}424.9344 \\
(543.4589)\end{array}$ & $\begin{array}{l}469.8885 \\
(547.2721)\end{array}$ & $\begin{array}{l}443.0347 \\
(543.3154)\end{array}$ & $\begin{array}{l}413.43254 \\
(549)\end{array}$ \\
\hline Feel Negative about Interest Rate Next 5 Years & $\begin{array}{l}-697.5229 \\
(581.6892)\end{array}$ & $\begin{array}{l}-751.0275 \\
(586.0626)\end{array}$ & $\begin{array}{l}-461.7219 \\
(601.5489)\end{array}$ & $\begin{array}{l}-520.387 \\
(599.0573)\end{array}$ & $\begin{array}{l}-473.4062 \\
(596.3258)\end{array}$ & $\begin{array}{l}-580.81318 \\
(611)\end{array}$ \\
\hline Risk Loving & $\begin{array}{l}-1556.651 \\
(1014.181)\end{array}$ & $\begin{array}{l}-1514.63 \\
(1018.475)\end{array}$ & $\begin{array}{l}-1553.936 \\
(1026.918)\end{array}$ & $\begin{array}{l}-1521.79 \\
(1034.137)\end{array}$ & $\begin{array}{l}-1498.283 \\
(1026.724)\end{array}$ & $\begin{array}{l}-1529.0584 \\
(1024)\end{array}$ \\
\hline Employed & $\begin{array}{l}3832.765 \\
(631.373)\end{array}$ & $\begin{array}{l}4033.461 \\
(629.3493)\end{array}$ & $\begin{array}{l}3934.472 \\
(634.8882)\end{array}$ & $\begin{array}{l}3892.492 \\
(639.8311)\end{array}$ & $\begin{array}{l}3969.596 \\
(631.3697)\end{array}$ & $\begin{array}{l}3932.5572 * * * \\
(638)\end{array}$ \\
\hline Get Assistant in Financial Emergencies & $\begin{array}{l}253.2345 \\
(481.0163)\end{array}$ & $\begin{array}{l}222.2831 \\
(483.2431)\end{array}$ & $\begin{array}{l}323.5262 \\
(477.8271)\end{array}$ & $\begin{array}{l}222.9012 \\
(478.7093)\end{array}$ & $\begin{array}{l}316.5865 \\
(476.8391)\end{array}$ & $\begin{array}{l}267.7063 \\
(482)\end{array}$ \\
\hline Wage Salary & $\begin{array}{l}0.0160427 \\
(0.0060214)\end{array}$ & $\begin{array}{l}0.014267 \\
(0.0059115) \\
\end{array}$ & $\begin{array}{l}0.0139461 \\
(0.0061669)\end{array}$ & $\begin{array}{l}0.014907 \\
(0.005595) \\
\end{array}$ & $\begin{array}{l}0.0137819 \\
(0.0058874) \\
\end{array}$ & $\begin{array}{l}0.01458884 * * * \\
(0.006)\end{array}$ \\
\hline
\end{tabular}

\section{Conclusion}

This study investigated the factors that are likely to influence individuals who apply for a specific amount of student loan using a two-part model. The main assumption in this study was that the decision to apply for a loan and the amount of the loan are two different stochastic processes that govern an individual's behavior towards student loans. The study found that old age (41 years and older ), previous experience with bankruptcy, attitude towards borrowing to finance education, being Hispanic, employment status, and wage salary are the significant variables that can influence the amount a student will borrow. Moreover, this study found out that using the SCF data without accounting for the sampling and imputation errors inherent in the data set could lead to biased estimates and model inferences.

The results of this study would be useful to students' loan managers, both at the federal and commercial levels, to identify the factors that are likely to influence individuals to borrow, and the amount of money they might loan. More 
importantly, it could also help them to identify vulnerable and minority groups and increase their access to student loans. For instance, it has been observed in this study that people older than 40 years are more likely to decrease the amount of loan they might borrow. The same applies to a Hispanic borrower compared to an Asian borrower. Based on the results of this study, and the need to improve minority access to federal student loans, the study recommends that student's loan managers could introduce policies that would target Hispanics (and blacks) who are older (above 40). Moreover, students who feel it is not good to borrow for education financing might not be interested in student loans. There could be an educational program to target such students, especially minorities and vulnerable groups, to learn more about the federal student loan program, and the potential benefits such programs could have on their educational financing and overall college experience. The proposed program (s) could also include education regarding student loan bankruptcy and what steps they could take to avoid it.

\section{References}

Avery, C., \& Turner, S. (2012). Student loans: Do college students borrow too much—or not enough? The Journal of Economic Perspectives, 26(1), 165-192. https://doi.org/10.1257/jep.26.1.165

Baum, S., Ma, J., \& Payea, K. (2012). Trends in public higher education: Enrollment, prices, student aid, revenues, and expenditures. Retrieved from College Board Trends in Higher Education Series website: http://trends.collegeboard.org/sites/default/files/trends-2012-public-higher-educationexpenditures-brief. pdf.

Belotti, F., Deb, P., Manning, W. G., \& Norton, E. C. (2015). Two-part models. Stata. J., 15(1), 3-20.

Best, J., \& Best, E. (2014). The student loan mess: How good intentions created a trillion-dollar problem. Univ of California Press.

Board of Governors of the Federal Reserve System (2013). Survey of Consumer Finances. Retrieved (3/6/2017): https://www.federalreserve.gov/econresdata/scf/scfindex.htm

Brown, M., Haughwout, A., Lee, D., Scally, J., \& Van Der Klaauw, W. (2015). Measuring student debt and its performance. Student Loans and the Dynamics of Debt, 37-52. https://doi.org/10.17848/9780880994873.ch3

Cameron, A. C., \& Trivedi, P. K. (2005). Microeconometrics: methods and applications. Cambridge University Press. https://doi.org/10.1017/cbo9780511811241

Cellini, S. R., \& Goldin, C. (2014). Does federal student aid raise tuition? New evidence on for-profit colleges. American Economic Journal: Economic Policy, 6(4), 174-206. https://doi.org/10.1257/pol.6.4.174

Cohen, A. M., \& Kisker, C. B. (2009). The shaping of American higher education: Emergence and growth of the contemporary system. San Francisco, CA: Jossey-Bass.

Dynarski, S. M. (2015). An economist's perspective on student loans in the United States.

Fuller, M. B. (2014). A history of financial aid to students. Journal of Student Financial Aid, 44(1), 4.

Grafova, I. B. (2007). Your money or your life: Managing health, managing money. Journal of Family and Economic Issues, 28(2), 285-303. https://doi.org/10.1007/s10834-007-9060-0

Greiner, K. (1996). How Much Student Loan Debt Is Too Much? Journal of Student Financial Aid, 26(1), 7-16

Gross, J. P., Cekic, O., Hossler, D., \& Hillman, N. (2009). What matters in student loan default: A Review of the research literature. Journal of Student Financial Aid, 39(1), 19-29.

Hillman, N. W. (2014). College on credit: A multilevel analysis of student loan default. The Review of Higher Education, 37(2), 169-195. https://doi.org/10.1353/rhe.2014.0011

Li, W. (2013). The economics of student loan borrowing and repayment. Business Review, (Q3), 1-10.

Lochner, L., \& Monge-Naranjo, A. (2015). Student loans and repayment: Theory, evidence and policy (No. w20849). National Bureau of Economic Research. https://doi.org/10.3386/w20849

Lucca, D. O., Nadauld, T., \& Chen, K. (2016). Credit supply and the rise in college tuition: evidence from the expansion in federal student aid programs.

Montalto, C. P., \& Sung, J. (1996). Multiple imputation in the 1992 Survey of Consumer Finances. Journal of Financial Counseling and Planning, 7.

Nielsen, R., \& Seay, M. C. (2012). CPS Complex Sample Specification for SAS and STATA. Available at SSRN 2061582. https://doi.org/10.2139/ssrn.2061582

Pence, K. M. (2001). 401 (k) s and household saving: New evidence from the Survey of Consumer Finances. 
Shin, S. H., \& Hanna, S. D. (2016). Accounting for complex sample designs in analyses of the Survey of Consumer Finances. Journal of Consumer Affairs. https://doi.org/10.1111/joca.12106

Walsemann, K. M., Gee, G. C., \& Gentile, D. (2015). Sick of our loans: Student borrowing and the mental health of young adults in the United States. Social Science \& Medicine, 124, 85-93.

https://doi.org/10.1016/j.socscimed.2014.11.027

\section{Copyrights}

Copyright for this article is retained by the author(s), with first publication rights granted to the journal.

This is an open-access article distributed under the terms and conditions of the Creative Commons Attribution license which permits unrestricted use, distribution, and reproduction in any medium, provided the original work is properly cited. 